\title{
Advances in stallion's epididymal sperm technology
}

\author{
Cely M. Melo, Gabriel A. Monteiro, Bruno R. Avanzi, Priscilla N. Guasti, Marco A. Alvarenga, José A. Dell'Aqua Jr, Fabiola S. Zahn \\ and Frederico O. Papa
}

Department of Animal Reproduction and Veterinary Radiology, São Paulo State University, SP, Brazil

\begin{abstract}
Summary
Freezing epididymal sperm is a method to preserve germplasm from animals with not only high genetic potential but also endangered species. In the equine some owners have chosen this possibility in cases of either severe illness or death of stallions. However, the lack of knowledge and poor published results of such technique hampers its propagation. New procedures have allowed some improvement on fertility rates of frozen sperm from the epididymis of stallions. The aim of this study is to report the advances on processing and cryopreservation of samples from the stallion's epididymal semen.
\end{abstract}

Keywords: epididymis, cryopreservation, stallion, fertility, semen extenders, artificial insemination

\section{Fortschritte in der Technologie von Nebenhodensperma beim Hengst}

Das Einfrieren von Nebenhodensperma ist eine Methode, die es erlaubt, Erbinformationen von Tieren mit außergewöhnlich hohem genetischen Potential sowie von bedrohten Tierarten zu konservieren. Beim Pferd wird diese Möglichkeit von einigen Besitzern bei schwerer Krankheit oder Tod des Hengstes genutzt. Jedoch wird die Propagierung dieser Methode durch den mangelhaften Wissenstand sowie wenige publizierte Daten gehemmt. Neuere Verfahren erlauben eine gewisse Verbesserung der Fertilitätsraten anhand gefrorenen epididymalen Spermas von Hengsten. Ziel dieser Studie ist, den Fortschritt in der Methodik zur Aufbereitung und Konservierung von Proben aus dem Nebenhoden des Hengstes zu beschreiben.

Schlüsselwörter: Epidydimis, Gefrierkonservierung, Hengst, Fruchtbarkeit, Samenextender, künstliche Insemination

\section{Introduction}

Unexpected death, catastrophic injury, castration or any other event that makes both semen collection and mating impossible can be costly in terms of the potential loss of genetically valuable stallion genes. In such circumstances, owners may request a final semen collection to allow propagation of valuable germplasm (Cary et. al. 2004). There are limited data regarding survival and fertility of frozen-thawed epididymal stallion sperm, although the first pregnancy using frozen-thawed stallion spermatozoa was reported in a mare inseminated with epididymal spermatozoa (Barker and Gandier 1957). Stallion sperm capable of fertilization can be harvested from the cauda epididymis (Barker and Gandier 1957, Johnson et al. 1980) and stored for future use, preserving valuable gene pool. The timing and, often, location for either castration or post-mortem tissue recovery are not always appropriate for sperm handling and preservation.

Over the years, different techniques for semen collection and cryopreservation have been developed, but few researches have focused on obtaining and freezing epididymal sperm cells from stallions. Therefore, the aim of the present study is to review the recent advances in preservation of equine epididymal sperm.

\section{Epididymal removal and shipment}

After the removal of epididymides and testicles it is necessary to ligate the ductus deferens using suture material to avoid the loss of sperm cells. The ligature should be performed the farthest possible from epididymal cauda, once viable sperms can be obtained from this region. The testicles and epididymides should be rinsed using an isotonic solution, as Lactated Ringer's or saline solution, to remove blood and contaminants. They should then be put into plastic bags or rectal gloves, with less minimal air possible (Eichelberger et al. 2007).

Epididymides can be either shipped in passive cooling devices to a specialized facility or processed immediately (Bruemmer 2006). Samples obtained from epididymides of different species can be stored at 50C for 24 hours prior to cryopreservation (Marks et al. 1994, Blash et.al., 2002, Sharma et. al., 2007, Papa et al., 2008). However, there is a significant decrease after 12 hours of storage at room temperature on the sperm parameters at 5oC (Monteiro et al., 2009a).

\section{Collection of epididymal sperm}

Sperm from terminal stallions may be obtained via electroejaculation (Cary et al. 2004), chemical ejaculation (Card et al. 1997, McDonnell 2001) or by the collection of sperm from cauda epididymides (Morris et al. 2002. James et al. 2002, James 2004, Muradás et al. 2006, Papa et al. 2008). Electroejaculation is a widely spread and successful method for semen collection in some species like the bovine and the ovine, but its use in stallions is not advisable due to the risks for both the animal and practitioner (Stover et al. 1981). 
According to Cary et al. (2004), electroejaculation is not an efficient technique to obtain viable sperm, since semen is contaminated with urine even when ejaculation is achieved. In the same experiment, viable sperm was obtained from cauda epididymides, allowing cryopreservation of sperm from valuable stallions, whose semen collection was unsuitable.

Several methods of sperm recovery from cauda epididymis have been described, including aspiration (Sharma et al., 1997), flotation - in which sliced epididymis is placed on gel medium for some time (Hewitt et al., 2001), and retrograde flush of the cauda - in which pressure is generated by a syringe attached to the vas deferens and sperm is carried by the extender and expelled through a cut on the junction of cauda and corpus (Garde et al. 1994).

Martinez-Pastor et al. (2006) compared the retrograde flush and flotation techniques for the recovery of epididymal sperm and they have obtained a higher number of sperm using retrograde flush. In addition, the sample obtained by this technique did not present other cell types, which may be considered an important advantage of this technique.

Several studies have shown that equine epididymal sperm remains viable at room temperature for $24 \mathrm{~h}$ after orchiectomy (Muradás et al. 2006, Neild et al. 2006, Papa et al. 2008), and thus can be used for artificial insemination of either fresh or frozen sperm (Barker and Gandier 1957, Morris et al. 2002, Papa et al. 2008). Besides, another study demonstrated that the number of spermatozoa recovered from the cauda epididymis is higher than the one recovered from artificial vagina on a single collection (Muradás et al. 2006). If cauda epididymis sperm recovery is the last chance to obtain viable spermatozoa from a stallion, it is of utter importance to test protocols to enhance the success rates of this technology in stallions.

It has also been demonstrated that spermatozoa obtained from stallion epididymis after dilution with suitable extender present similar progressive motility when compared to ejaculated sperm obtained by artificial vagina (Morris et al. 2002).

Due to a lack of information concerning the storage capability of epididymis and total number of spermatozoa that can be obtained from the epididymal tail, Papa et al. (2008) correlated testicular volume (length $\times$ width $\times$ height) and testicular weight with the recovery of epididymal spermatozoa retrie- val (Table 1 and 2). Testes were obtained during routine castration from twenty-two Brazilian jumping horses aging approximately 3 years old. The authors observed a positive correlation between testicular volume and weight. Testicular parameters are described on table 1.

\section{Preservation of epididymal sperm}

Bruemmer et al. (2002) tested the cryopreservation of equine sperm collected from cauda epididymis. After collection, some of the samples were frozen directly and the others were stored for $24 \mathrm{~h}$ at $5^{\circ} \mathrm{C}$ before freezing, using INRA 82 and EDTA-Lactose extenders. The authors observed that storage at 5oC did not affect total and progressive motility when compared to the samples that had been directly frozen. Papa et al (2008) observed an increase in pre- and post-freezing results of samples frozen with Botu-Crio ${ }^{\circledR}$ when compared to EDTALactose and INRA-82.

In order to verify the effect of storage time at $4^{\circ} \mathrm{C}$, James et al. (2002) collected cauda epididymis sperm from 17 stallions and stored for a total period of $96 \mathrm{~h}$. Samples were analyzed every $24 \mathrm{~h}$ for progressive motility and viability based on eosin-nigrosin/fast-green staining. Both motility and viability significantly decreased between consecutive periods but the authors concluded that it was possible to freeze epididymal sperm up to $96 \mathrm{~h}$ after collection, if it is maintained at $4^{\circ} \mathrm{C}$.

Epididymal sperm presents very poor motility, which is probably due to the lack of exposure to activating factors present in the seminal plasma (Stout et al. 1999). Some studies have been investigating the influence of seminal plasma (Stout et al. 1999, Papa et al. 2008) and sperm motility factors such as caffeine, progesterone, PHE (penicillamine, hypotaurine and epinephrine) and heparine (Papa et al. 2008).

Pasquini et al. (2008) compared the influence of motility enhancing media on freezability of epididymal sperm and concluded that incubation in Talp + P4, Fert-Talp and SpermTalp media, commonly used in IVF procedures, improved equine epididymal sperm motility after freezing (Table 3). Based on these results, Melo et al. (2009) evaluated the influence of those substances on epididymal sperm from subfertile stallions after freezing and verified a pre and post-thaw motility improvement when samples were incubated with Sperm-Talp and Fert-Talp in comparison to ejaculated frozen

Table 1 Mean $( \pm S D)$ testicle parameters from equine testis collected post-castration Mittelwerte $( \pm S D)$ testikulärer Parameter von durch Kastration gewonnenen equinen Hoden

\section{Testicle parameters}

\begin{tabular}{cccccccc}
\hline \multicolumn{9}{c}{ Left } & \multicolumn{3}{c}{ Right } \\
Length $(\mathrm{cm})$ & Height $(\mathrm{cm})$ & Width $(\mathrm{cm})$ & Weight $(\mathrm{g})$ & Length $(\mathrm{cm})$ & Height $(\mathrm{cm})$ & Width $(\mathrm{cm})$ & Weight $(\mathrm{g})$ \\
$9.5 \pm 1.0$ & $6.2 \pm 0.7$ & $5.1 \pm 0.5$ & $195.0 \pm 62.5$ & $9.1 \pm 1.5$ & $5.8 \pm 1.2$ & $4.9 \pm 0.8$ & $183.2 \pm 75.2$ \\
\hline
\end{tabular}

Table 2 Mean $( \pm S D)$ parameters from equine epididymal flush collected post-castration Mittelwerte $( \pm S D)$ von Parametern equiner epididymaler Spülproben nach Kastration

\begin{tabular}{ccc}
\hline & Semen parameters \\
\hline Epididymal Flush $(\mathrm{mL})$ & Concentration $\left(\mathrm{sperm} / \mathrm{mL} \times 10^{6}\right)$ & Total sperm number $\left(\right.$ sperm $\left.\times 10^{9}\right)$ \\
$51.1 \pm 7.5$ & $103.5 \pm 78.1$ & $4.8 \pm 3.3$ \\
\hline
\end{tabular}


Table 3 Mean $( \pm S D)$ values of post-thaw total motility (TM), progressive motility (PM), curvilinear velocity (VCL), straight line velocity (VSL) and percentage of rapid cells (RAP) of equine epididymal sperms incubated with different media and frozen with Botucrio extender

Mittelwerte ( $\pm S D$ ) nach dem Auftaven: Gesamtmotilität (TM), vorwärtsbewegliche Spermien (PM), kurvolineare Geschwindigkeit (VCL), lineare Geschwindigkeit (VSL) und Prozentsatz schneller Zellen (RAP) von equinen epididymalen Spermien nach Inkubation mit verschiedenen Medien und Einfrieren mit Botucrio-Verdünner

\begin{tabular}{cccccc}
\hline Group & TM (\%) & PM (\%) & VSL $(\mu \mathrm{m} / \mathrm{s})$ & VCL $(\mu \mathrm{m} / \mathrm{s})$ & RAP $(\%)$ \\
\hline Control & $44.6 \pm 13.2^{\mathrm{b}}$ & $19.2 \pm 5.7^{\mathrm{bc}}$ & $71.7 \pm 3.0^{\mathrm{ab}}$ & $167.6 \pm 7.9$ & $30.9 \pm 9.9^{\mathrm{b}}$ \\
P4 & $49.9 \pm 5.0^{\mathrm{ab}}$ & $21.7 \pm 2.3^{\mathrm{abc}}$ & $72.6 \pm 2.1^{\mathrm{ab}}$ & $169.9 \pm 7.4$ & $35.1 \pm 4.5^{\mathrm{ab}}$ \\
Plasma & $46.2 \pm 12.9^{\mathrm{b}}$ & $17.7 \pm 5.1^{\mathrm{c}}$ & $68.0 \pm 5.6^{\mathrm{b}}$ & $161.3 \pm 17.8$ & $30.1 \pm 12.2^{\mathrm{b}}$ \\
Fert & $58.2 \pm 7.9^{\mathrm{ab}}$ & $24.7 \pm 4.2^{\mathrm{ab}}$ & $73.0 \pm 4.7^{\mathrm{ab}}$ & $169.7 \pm 13.0$ & $42.0 \pm 8.8^{\mathrm{ab}}$ \\
Talp & $61.7 \pm 7.1^{\mathrm{a}}$ & $26.4 \pm 1.6^{\mathrm{a}}$ & $74.4 \pm 2.5^{\mathrm{a}}$ & $175.4 \pm 10.4$ & $45.4 \pm 6.6^{\mathrm{a}}$ \\
\hline
\end{tabular}

* Different letters in a column differ significantly $(\mathrm{P}<0.05)$. Control (Botu-Semen); P4 (Talp + Progesterone); Plasma (Seminal Plasma); Fert (Fert-Talp); Talp (Sperm-Talp)

Table 4 Mean values for Total Motility (TM), Progressive Motility (PM) and Plasma Membrane Integrity (PMI) of ejaculated and frozen-thawed epididymal semen from poor freezer stallions incubated with Botu-Semen (BS), Talp + caffeine (Sp) and Talp + Heparine + PHE (Fert) Mittelwerte der Gesamtmotilität (TM), vorwärtsbeweglicher Spermien (PM) und der Plasmamembranintegrität (PMI) von ejakuliertem und tiefgefrorenem epididymalen Samen von Hengsten mit schlechter Samengefriereignung nach Inkubation mit Botu-Samenverdünner (BS), Talp + Koffein (Sp) und Talp + Heparin + PHE (Fert)

\begin{tabular}{|c|c|c|c|}
\hline & $\mathrm{TM}$ & PM & PMI \\
\hline Ejaculate & $7.7 \pm 2.21^{c}$ & $1.7 \pm 1.26^{b}$ & $22.3 \pm 6.02^{b}$ \\
\hline BS & $33.3 \pm 2.10^{b}$ & $12.5 \pm 3.31^{a}$ & $41.7 \pm 10.59^{\circ}$ \\
\hline Sp & $41.3 \pm 3.77^{\circ}$ & $14.3 \pm 2.61^{\mathrm{a}}$ & $41.5 \pm 2.38^{a}$ \\
\hline Fert & $42.0 \pm 1.63^{a}$ & $15.25 \pm 3.94^{\circ}$ & $47.2 \pm 2.87^{a}$ \\
\hline
\end{tabular}

* Different letters in a column differ significantly $(P<0.05)$

Table 5 Mean values for Total Motility (TM), Progressive Motility (PM) and Plasma Membrane Integrity (PMI) of semen collected with artificial vagina $(G 1)$, recovered from epididymal cauda immediately post-orchiectomy (G2) and recovered from epididymal cauda stored for 24 hours at $5^{\circ} \mathrm{C}(\mathrm{G} 3)$.

Mittelwerte der Gesamtmotilität (TM), vorwärtsbeweglicher Spermien (PM) und der Plasmamembranintegrität (PMI) von Sperma gewonnen mit Hilfe der künstlichen Vagina (G1), aus dem Nebenhodenschwanz unmittelbar nach Kastration (G2) und aus dem Nebenhodenschwanz nach Aufbewahrung bei $5^{\circ} \mathrm{C}$ für 24 Stunden (G3)

\begin{tabular}{ccrr}
\hline & TM & PM & PMI \\
\hline G1 & $60.2 \pm 16.99^{\mathrm{b}}$ & $30.8 \pm 14.22^{\mathrm{b}}$ & $41.2 \pm 20.32^{\mathrm{b}}$ \\
G2 & $85.1 \pm 5.85^{\mathrm{a}}$ & $46.1 \pm 8.46^{\mathrm{a}}$ & $74.9 \pm 10.49^{\mathrm{a}}$ \\
G3 & $83.1 \pm 7.52^{\mathrm{a}}$ & $38.3 \pm 7.14^{\mathrm{ab}}$ & $71.7 \pm 9.85^{\mathrm{a}}$ \\
\hline
\end{tabular}

* Different letters in a column differ significantly $(\mathrm{P}<0.05)$

semen, probably due to the deleterious effect of seminal plasma in poor semen stallions (Table 4).

Pentoxifylline is a substance that promotes the increase of the $A M P c$, which is responsible for the spermatic motility, being able to stimulate recently recovered immobile spermatozoa. The use a skim-milk extender containing pentoxifillyne, BotuTurbo (BT) for equine epididymal semen increased total and progressive motility in comparison to the skim-milk extender Botu-Semen (B). Sperm parameters of the flushed samples with BT and B immediately after flushing for Total Motility (TM) were $47.4 a \pm 22.8$ vs 19.2b 14.1 . As for the Progressive Motility (PM) they were $16.7 a \pm 9.5$ vs $6.5 b \pm 7.2$. After 15 minutes of incubation at $37^{\circ} \mathrm{C}$ sperm values for TM, PM were $67.4 a \pm 21.9$ vs $48.7 b \pm 29.1$ and $22.6 a \pm 10.0$ vs $12.4 \mathrm{~b} \pm 8.8$, respectively (Guasti et al. 2009).

A recent study conducted by Monteiro et al (2009a) compared post-refrigeration viability of ejaculated sperm collected by artificial vagina and epididymal sperm recovered immediately after castration. Parameters (total and progressive motility and membrane integrity) of epididymal sperm cooled at $5^{\circ} \mathrm{C}$ for both 24 and $48 \mathrm{~h}$ were significantly superior to those from ejaculated sperm $(P<0.05)$, demonstrating that epididymal sperm are less susceptible to damages caused by refrigeration procedures (Table 5).

\section{Influence of seminal plasma on fertility of epididymal sperm}

Some authors believe that the reduced fertility of frozen epididymal semen is due to the absence of seminal plasma, the only difference between ejaculated and epididymal sperm. Seminal plasma has an important role on motility, membrane integrity and uterine transport, and its absence shall be deleterious (Aurich 1996, Katila 2001).

The presence of decapacitating factors in the seminal plasma inhibits the sperm capacitation, avoiding the early acrosomal reaction and could prevent fertilization (Oliphant et. al. 1985). According to some studies, there is no effect of seminal plasma on epididymal spermatozoa (Cary et al. 2004, Morris et al. 2002, Tiplady et al. 2002 and Volkmann et al. 2001). Seminal plasma can play positive influence upon the fertility of epididymal sperm (Heise et al. 2009), however it is 
not strictly necessary to achieve the conception (Morris et al. 2002, Papa et al. 2008).

\section{Fertility of epididymal sperm}

Although the first pregnancy with frozen semen in horses was obtained with cauda epididymides sperm, studies in equine semen have been restricted to ejaculated sperm. Only in the last few years studies in recovery and preservation of epididymal sperm have been intensified, in part due to the increasing interest in preservation of endangered species or high valuable genetics, and also owing to the possibility of low dose artificial insemination and ICSI in horses.

Morris (2004) reported a $45 \%$ pregnancy rate after hysteroscopic inseminations of mares with $200 \times 10^{6}$ fresh cauda epididymis sperm. Using the same dose but frozen-thawed epididymal sperm, this author obtained pregnancy rates of 18 and $8 \%$ when mares were inseminated by hysteroscopy or by conventional method, respectively. This demonstrated the possibility of obtaining pregnancies from epididymal sperm even with low doses.

Papa et al. (2008) reported $66.6 \%$ conception rate after inseminations with $400 \times 10^{6}$ viable epididymal sperm cooled for $24 \mathrm{~h}$ at $5^{\circ} \mathrm{C}$ pre and post ovulation. A subsequent study was conducted by Monteiro et al. (2009b) in order to compare post thaw fertility of ejaculated sperm (Group 1), epididymal sperm frozen immediately after castration (Group 2) and epididymal sperm frozen after $24 \mathrm{~h}$ refrigeration at $5^{\circ} \mathrm{C}$ (Group 3). All inseminations were performed with $800 \times 10^{6}$ viable sperm in the tip of uterine horn. Conception rates were, respectively, $61.5 \%$ (8/13), $92.3 \%(12 / 13)$ and $61.5 \%$ (8/13) for groups 1,2 and 3 .

Herrera et al. (2006) reported no difference in embryo cleavage rates using ICSI in equine oocytes matured in vitro when frozen cauda epididymal semen, in natura ejaculated or frozen ejaculated sperm were used, demonstrating that epididymal sperm are suitable for ICSI procedures in horses.

\section{Conclusion}

Results presented in this review allow us to conclude that cauda epididymis stallion sperm may be successfully used in reproductive biotechnologies, making possible the use of fresh, cooled or frozen sperm from stallions that had their reproductive life interrupted, maintaining the production of genetically superior animals. More studies using lower doses have to be developed aiming to optimize the use of epididymal frozen semen using different technologies, such as artificial insemination, intracytoplasmatic sperm injection and in vitro fertilization.

\section{References}

Aurich J. E., Kühne A., Hoppe H. and Aurich C. (1996) Seminal plasma effects membrane integrity and motility of equine spermatozoa after cryopreservation. Theriogenology. 46, 791-797

Barker C. A. and Gandier S. C. C. (1957) Pregnancy in a mare resulting from frozen epididymal spermatozoa. Can. J. Comp. Med. $21,47-51$
Blash S., Melican D. and Gavin W. (2002) Cryopreservation of epididymal sperm obtained at necropsy from goats. Theriogenology. 54, 899-905

Bruemmer J. E., Reger H., Zibinski G. and Squires E. L. (2002) Effect of storage at $5^{\circ} \mathrm{C}$ on the motility and cryopreservation of stallion epididymal spermatozoa. Theriogenology 58, 405-407

Bruemmer J. M. (2006) Collection and freezing on epididymal stallion sperm. Ani. Reprod. Sci. 22, 677-682.

Card C. E., Manning S. T., Bowman P. and Leibel T. (1997) Pregnancies from imipramine and xylazine- induced ex copula ejaculation in a disabled horse. Can. Vet. J. 38, 171-174

Cary J. A., Madill S., Farnsworth K., Hayna J. T., Duoos L. and Fahning M. L. (2004) A comparison of electroejaculation and epididymal sperm collection techniques in stallions. Can. Vet. J. 45, 35-41

Eichelberger A. C., Troedsson M. H., Pozor M. A. and Macpherson M. L. (2007) How to Collect, Handle, and Process Post-Mortem Epididymal Sperm for Breeding or Assisted Reproductive Techniques. AAEP Proceedings, 53, 583-586

Garde J., Aguado M., Perez S., Garrido D., Perez-Guzman M. and Montoro V. (1994) Physiological characteristics of epididymal spermatozoa from postmortem rams. Theriogenology. 41, 203

Guasti P. N., Monteiro G. A., Dell'Aqua Júnior J. A., Melo C. M., Crespilho A. M., Maziero R. R. D., Martin J. C. and Papa F. O. (2009) Viability of equine frozen epididymal sperm treated with pentoxifylline. Proceedings of 11 th Congress of the World Equine Veterinary Association. Cd-rom

Heise A., Kähn W., Volkmann D. H., Thompson P. N. and Gerber D. (2009) Influence of seminal plasma on fertility of fresh and frozen-thawed stallion epididymal spermatozoa, Anim Reprod Science. In press

Herrera C., Miragaya H. M., Conde P., Hynes V., Losinno L., Quintans C. and Pasqualini R. S. (2006) Intracytoplasmatic injection of in vitro-matured equine oocytes with frozen-thawed epididymal sperm. Anim. Reprod. Sci. 94, 299-302

Hewitt D. A., Leahy R., Sheldon I. M. and England G. C. W. (2001) Cryopreservation of epididymal dog sperm. Anim. Reprod. Sci. 67, 101-111

James A. N. (2004) Preservation of sperm harvested from the rat, caprine, equine and bovine epididymis. PhD Thesis. Faculty of the Lousiana State University and Agricultural and Mechanical College, Baton Rouge, 229

James A. N., Green H., Hoffman S., Landry A. M., Paccamonti D. and Godke R. A. (2002) Preservation of equine sperm stored in the epididymis at 4 C for 24, 48, 72 and 96 h. Theriogenology 58, 401-404

Johnson L., Amann R. P. and Pickett B. W. (1980) Maturation of equine epididymal spermatozoa. Am. J. Vet. Res. 41, $1190-1196$

Katila T. (2001) Sperm-uterine interactions: a review. Anim. Reprod. Sci. 68, 267-272

Marks S. L., Dupus J., Mickelsen W. D., Memon M. A. and Platz C. C. Jr. (1994) Conception by use of postmortem epididymal semen extraction in a dog. J. Am. Vet. Med. Assoc. 204, 1639-1640

Martinez-Pastor F., Macias V. G., Alvarez M., Chamorro C., Herraez P., Paz P. and Anel L. (2006) Comparison of two methods for obtaining spermatozoa from the cauda epididymis of Iberian red deer. Theriogenology 65, 471-485

McDonnell S. M. (2001) Oral imipramine and intravenous xylazine for pharmacologically-induced ex copula ejaculation in stallions. Anim. Reprod. Sci. 68, 153-159

Melo C. M., Papa F. O., Monteiro G. A., Guasti P. N., Avanzi B. R., Landim-Alvarenga F. C., Alvarenga M. A. and Dell'aqua Junior J. A. (2009) Improvement of frozen epididymal semen from subfertile stallions using sperm motility factors. Proceedings of 11 th Congress of the World Equine Veterinary Association. Cd-rom

Monteiro G. A., Guasti P. N., Dell'Aqua Jr. J. A., Melo C. M., Martin J. C., Maziero R. R., Avanzi B. R. and Papa F. O. (2009a) Viability of sperm harvested fom epididymal cauda stored in different moments and temperatures. Proceedings of 11 th Congress of the World Equine Veterinary Association. Cd-rom

Monteiro G. A., Guasti P. N., Melo, C. M., Dell'Aqua Jr. J. A., Martin J. C., Carneiro R. and Papa F. O. (2009b) Comparison between cooled sperm from ejaculate and epididymal cauda. Proceedings of 11 th Congress of the World Equine Veterinary Association. Cd-rom 
Morris L. H. A. (2004) Low dose insemination in the mare: an update. Anim. Reprod. Sci. 82, 625-632

Morris L. H. A., Tiplady C. and Allen W. R. (2002) The in vivo fertility of cauda epididymal spermatozoa in the horse. Theriogenology $58,643-646$

Muradás P. R., Weiss R. R., Kozicki L. E., Granemann L. C., Santos 1. W. and Pimpão C. T. (2006) Alguns parâmetros de viabilidade de espermatozóides equinos colhidos por vagina artificial e por lavagem da cauda do epidídimo. Arch. Vet. Sci. 1 1, 69-74

Neild D., Miragaya M., Chaves G., Pinto M., Alonso A., Gambarotta M., Losinno L. and Aguero A. (2006) Cryopreservation of cauda epididymis spermatozoa from slaughterhouse testicles $24 \mathrm{~h}$ after ground transportation. Anim. Reprod. Sci. 94, 92-95

Oliphant G., Reynolds A. B. and Thomas T. S. (1985) Sperm surface components involved in the control of the acrosome reaction. Am. J. Anat. 174, 269-283

Papa F. O., Melo C. M., Fioratti E. G., Dell'Aqua Jr. J. A., Zahn F. S. and Alvarenga M. A. (2008) Freezing of stallion epididymal sperm. Anim. Reprod. Sci. 107, 101-111

Pasquini D. F., Melo C. M., Papa F. O., Fioratti E. G., Landim-Alvarenga F. C., Alvarenga M. A., Zahn F. S., De Vita B. and Dell'Aqua Jr. J. A. (2008) Effects of seminal plasma and sperm motility factors on viability of epididymal sperm of stallions. Anim. Reprod. Sci. 107, 338-339

Sharma R. K., Padron O. F., Thomas A. J. and Agarwal A. (1997) Factors associated with the quality before and after thawing of sperm obtained by microsurgical epididymal aspiration. Fertil. Steril. 68, 626-631
Stout T. A. E., Morris L. H. A., Li X. and Allan R. W. (1999) The effects of seminal plasma on motility and cryopreserbility of horse epididymal sperm. In: Proceedings of the Havemeyer Foundation Workshop: European Equine Gamete Group, 5-6

Stover J., Seager S. W. J., Dolensk E. P., Doherty J., Wildt D. F. and Platz C. C. (1981) Electroejaculation and semen evaluation of the Przewalski horse (Equus przewalski). Am. Assoc. Zoo. Vet. 144-145

Tiplady C. A., Morris L. H. A. and Allen W. R. (2002) Stallion epididymal spermatozoa: pre-freeze and post-thaw motility and spermatozoa: viability after three treatments (Abstract). Theriogenology 58, 225-228

Volkmann D. H., Gerber D. and Erb H. N. (2001) Comparison between freezability of ejaculated and epididymal stallion sperm (Abstract). Anim. Reprod. Sci. 68, 340

Frederico Ozanam Papa

Faculdade de Medicina Veterinária e Zootecnia

Distrito de Rubião Junior $s / n$

18618-000 Botucatu SP, CEP

Brazil

papa@fmvz.unesp.br 